\title{
Procurando unha ollada lila
}

\author{
Noelia Gómez Calvo
}

Pálpebras maquilladas cun ton lila que gardaba nun neceser no terceiro caixón do armario. O lapis está sen estrear e por iso lle manca nos ollos. Mais segue intentado pór cor na súa mirada.

Ao seu carón, hai un piano con algo de po. Fai tempo que non se deixa levar pola exorbitante sonoridade dun voar coas corcheas. Os apuntamentos de portugués, versos sen rematar de escribir e as reportaxes que nunca existiron. Fita inqueda cara á fiestra, ten ganas de voar. Ter o control da tinta, dos idiomas, dos seus traballos e dela mesma. Posuír unha fortaleza superior que a eleve ata o abismo da liberdade. Ela, unha poetisa con pegada violeta, non recoñece a diferenza entre o mundo ficticio das súas historias e a propia realidade.

Como lle ía ocorrer a ela? Unha loitadora, independente e revolucionaria muller que, dende cativa, dicía con orgullo que mamá era quen traía o diñeiro á casa. Psicóloga para familiares, amigas e calquera que escribira con anterioridade esta historia.

O grosor do lapis decora a súa ollada felina. Observa un reflexo, mais non é ela. Só sente impotencia por non ser quen de fechar esa porta escura. Feminista dende cativa, ela que lle prometera á súa avoa non caer na mala sorte de ser consumida igual que a chama dunha candea.
Nin Como Nicolas Cage in Leaving Las Vegas a fan espirse e sentirse única, como sempre o fixera.

Quizais foi o solpor do verán ou a primeira hostia a que a fixo reaccionar. Aquel xa non era o seu lugar. $\mathrm{O}$ medo a que se descubrise o seu segredo facíaa tremer. Houbo ríos de bágoas, desculpas e noites nas que no papel xa non existía a tinta violeta.

Lía a Simone de Beauvoir, a Rosalía de Castro, a Doris Lessing, a Camille Paglia, a Betty Friedan, a Judith Butler, a Alice Walker, a Clara Campoamor, a Virginia Bolten... e os seus propios "bosquexos lilas" cunha máscara. Un ceo apagado, un lóstrego, unha hostia.

Naquel tempo irreal, adoitaba amencer cun pano nos ollos e continuar a súa rutineira vida. Pór cor violeta nas pálpebras e camiñar descalza baixo eses toxos que tanta dor lle facían.

Non se sabe se foi ela ou a outra, a do reflexo do espello, a que, cun berro, arrincou o suxeitador e esa pintura da cara. Libertinaxe dese camiño de amargura.

Abriu a fiestra.

A música volveu a ela, a tinta do lapis volveu a recuperar a súa cor habitual mentres paseniño a súa ollada reflectida no espello volvía recuperar a luminosidade e a valentía. Volvendo así ser ela mesma. 